\title{
REX og nogle af dens brugere
}

\author{
Af forskningsbibliotekarvikar, mag.art. Bent L. Pedersen
}

I sommeren og efteråret 1990 blev der foretaget en lille undersøgelse af brugeres/låneres søgestrategier i Det kongelige Biblioteks database REX. Den blev foretaget som en kombination af interviews og de interviewedes s $\varnothing$ gninger (logs), der blev gemt på disketter. Undersøgelsen var led i en forskningsbibliotekars efteruddannelse på Danmarks Biblioteksskole.

Der er ikke tidligere foretaget en egentlig undersøgelse af, hvordan Det kongelige Biblioteks brugere anvender den elektronisk lagrede katalog i REX-basen. Idéen med undersøgelsen var at få nogle tilkendegivelser om brugeres/låneres metoder ved online søgninger af litteratur (dokumenter). Samtidig var det interessant at se om de foretagne søgninger gav en tilstrækkelig litteraturdækning for brugerne.

Indsamlingen af materialet foregik i Informationssalen på Det kongelige Bibliotek Slotsholmen og omfattede ialt $401 / 2$ time. Tidsrummet for indsamlingen faldt på forskellige tidspunkter mellem kl. 9 og 18 på 5 onsdage, 4 fredage, 3 tirsdage, 3 torsdage og 1 mandag. Den mest populære periode for brugere at foretage søgninger i lå mellem kl. 12 og 16. Der var stort set ingen REX-søgere mellem 9 og 10, og kun få mellem kl. 16 og kl. 18. Alt $\mathrm{i}$ alt indvilligede 55 personer $\mathrm{i}$ at deltage; heraf blev 21 interviewet $\mathrm{i}$ løbet af sommeren og 34 i løbet af efteråret.

Før selve resultatet af undersøgelsen beskrives, er det nødvendigt med en kort introduktion til REX-basen:

REX er en onlinekatalog for bestemte samlinger og biblioteker med dertil hørende informationer om deres indhold samt et online hjælpesystem. Katalogen indeholder referencer til danske og udenlandske bøger og tidsskrifter indgået i samlingerne og bibliotekerne fra ca. 1980 på Det kongelige Bibliotek, Universitetsbiblioteket 1. afdeling i Fiolstræde (København) og på Københavns Universitet Amager samt institutbibliotekerne ved Københavns 
Universitet inden for de humanistiske, teologiske og samfundsvidenskabelige områder (ca. 50 institutter). Derudover indeholder REX nogle specielle kataloger omfattende Dansk Musikfortegnelse fra 1981 og fremover, Orkesterkatalogen fra 1965 og fremover samt udenlandske tidsskrifter indgået 19501979 på Det kongelige Bibliotek. Basen omfatter for tiden (1990) omkring $1 / 2$ mill. poster.

REX kan anvendes som en fritekst søgebase, der indeholder et kommandosprogs søgesystem og et søgekodesystem. To hyppigt anvendte kommandoer, $s \varnothing g$ og vis, er det ikke nødvendigt at indtaste i almindelige s $\varnothing \mathrm{g}$ ninger, da man fra bibliotekets side vil gøre REX så let som muligt at anvende. Databasen er bygget op i registre; det vil sige, at ord, der forekommer $i$ en post, er lagt i en bestemt orden under de enkelte søgekoder, f. eks. forfatterregistret, titelregistret, emneordsregistret, eller i hovedregistret. Derfor er det både billigere og hurtigere at få en post hentet frem, hvis søgesproget anvendes. Men det er ikke nødvendigt, hvilket især er vigtigt for mindre rutinerede brugere. En sammenføjning af søgekoder og de kombinationsmuligheder REX indeholder (de boolske kombinatorer: og, eller, ikke) vil gøre søgningerne mere effektive og økonomiske.

$\begin{array}{lr}\text { BEGREB/FUNKTION: LOGISKE (BOOLSKE) OPERATORER } & \text { (Svar pá: ?boolsk) } \\ \text { (1. skærm af 2) } & \text { (<Retur> = ?boolsk2) }\end{array}$

De logiske (boolske) operatorer 'og', 'ikke', 'eller' kan anvendes for at gøre en søgning mere præcis. Man kan sáledes kombinere flere søgeord eller søgesæt med brug af disse operatorer.

Med 'og' indskrænkes søgningen og fællesmængden af de kombinerede termer angives. Med 'ikke' indskrænkes søgningen og differensmængden angives. Med 'eller' udvides søgningen og foreningsmængden angives.

Eks.: $\quad$ em $=$ france $\circ$ g em $=$ britain

giver records der handler om BADE Frankrig OG England

em=france ikke em=britain giver records der handler om Frankrig, MEN IKKE dem der ogsá handler om England

em=france eller em=britain giver records der handler om ENTEN Frankrig ELLER England

Bruges flere forskellige operatorer i een søgesætning, søger systemet først 'og'-kombinationen, derefter 'ikke'-kombinationen og til sidst 'eller'-kombinationen. Ønskes denne prioritering ændret, sættes 'eller'kombinationen i parentes med komma imellem leddene.

F.eks.: unemployment og (france,england)

De logiske operatorer kan ogsá angives ved brug af *,+ , ej (og, eller, ikke)

Se også:

?og

?eller ?ikke 
For mere avancerede søgninger kan trunkeringstegn, maskeringer af bogstaver, tegn eller ord og sammensætninger af delelementer evt. i kombination med tidligere søgninger yderligere tages i brug. I tvivlstilfælde kan en bruger få hjælp til søgninger i selve systemet ved at anvende et spørgsmålstegn eller ved en sammenføjning af tegnet med et ord f. eks. ?koder. REX har ca. 350 hjælpeskærme.

For at lette søgningerne for brugere, der kun ønsker at hente referencer i bestemte dele af databasen, er REX opdelt i flere delbaser (fagspecifikke eller samlingsspecifikke). En låner, der kun er interesseret i danske bøger, kan definere sin søgning i base 5 (Det kongelige Biblioteks Danske Samling) og supplere sin søgning i base 12 (Universitetsbiblioteket Amager og Universitetsbiblioteket Fiolstræde), hvorved låneren undgår udenlandske bøger samt samlinger og institutioner uden relevans til den aktuelle søgning.

Fremvisning af fundne referencer sker ved at taste $<$ Retur $>$, og de fremkommer i et standardformat, der for det meste fylder et halvt til et helt skærmbillede. Ved kombination af et søgenummer og én eller flere fundne referencer (records) kan der opnås et andet fremvisningsformat, som kan være mere formålstjentligt, f. eks. (vis) $s 4 ; r 3$ til $42 ; f 1$. Her vil brugeren få søgning nr. 4 med fund nr. 3 til og med 42 fremvist i det første format, der kun viser fundene (records) i én linie taget fra titelfeltet samt årstallet for publikationen. Dette format er særligt fremragende til at gennemgå mange fund, hvor brugeren kan udvælge de fund, der ønskes fremvist i et større og mere "fyldigt" format.

\begin{tabular}{|c|c|c|c|}
\hline \multicolumn{4}{|c|}{$\begin{array}{l}\text { Resultatet af søgning nr. } 4 \text { er } 527 \text { record(s) } \\
>\text { >vis s4; r3 til } 42 ; \text { f1 }\end{array}$} \\
\hline Rec.nr.- & Titel- Trykkeår- Afd.- & & \\
\hline r3 & Libra & 1988 & KUI \\
\hline 14 & Life in the Georgian city & 1990 & UBF \\
\hline r5 & The Viking collection : studies in northern civilization & 1983 & UBF \\
\hline r6 & Sexual anarchy : gender and culture at the fin de si'ecle & 1990 & KBU \\
\hline r7 & Viking ale : studies on folklore contacts between the north ${ }^{*}$ & 1991 & KBD \\
\hline r8 & Viking warriors & 1991 & KBD \\
\hline 19 & Sigtuna papers : proceedings of the Sigtuna Symposium on $\mathrm{Vi}^{*}$ & 1990 & KUI \\
\hline r10 & Vikingen : klubblad for Idrætsklubben Viking. Rønne & 1990 & KBD \\
\hline r11 & Towns in the Viking Age & 1991 & KUI \\
\hline r12 & Reflections & 1990 & KBU \\
\hline r13 & The Penguin dictionary of musical performers & 1990 & KUI \\
\hline r14 & Viking & 1937 & UBA \\
\hline r15 & Aurvandilsta: Norse studies & 1984 & KUI \\
\hline r16 & Stalin : the man and his era & 1973 & UBA \\
\hline r17 & American notes for general circulation & 1985 & KUI \\
\hline r18 & Stones, ships and symbols : the picture stones of Gotland $f^{*}$ & 1988 & KBU \\
\hline
\end{tabular}


Der er 5 fremvisningsformater i REX inklusiv inddateringsformatet. Standardfremvisningsformatet indeholder foruden almindelige bibliografiske oplysninger tillige systematiske koder, der for udenlandske bøgers vedkommende er forsynet med Det kongelige Biblioteks egne klassifikationskoder og emneord samt poster, der er genbrugt fra England eller USA, med Dewey klassifikationen og/eller Library of Congress klassifikationen og emneord.

\section{Udvalg og metode}

Deltagerne blev udvalgt før de gik i gang med deres søgninger i REX, idet de blev kontaktet, når de havde sat sig foran en terminalskærm, og spurgt, om de ville deltage. Reaktionerne var meget positive og flere deltagere håbede, at undersøgelsen kunne gøre det lettere for dem at $\varsigma \varnothing$ ge i REX. Dette er dog usikkert, da forskellige brugere har forskellige problemer og behov i deres søgninger. Kun ca. 15 pct. af de kontaktede personer afslog at deltage i undersøgelsen.

Når en deltager indvilligede $\mathrm{i}$ at deltage blev vedkommende bedt om at foretage sine søgninger i REX på en EDB maskine med en hård-plade uden indblanding fra undersøgeren. Skærmbilledet var det samme som på Informationssalens terminaler. Samtidig blev deltageren opfordret til at stille spørgsmål, hvis der opstod problemer i søgningen. Spørgsmålene kunne stilles til undersøgeren eller til informationspersonalet i salen. Desuden kunne søgeproblemer løses ved opslag på hjælpeskærme i REX. Ved udvælgelsen af personer bestræbte unders øgeren sig på at opnå en nogenlunde ligelig fordeling med hensyn til $k \emptyset n$ og alder, men da udvalget af deltagere afhang af antallet af terminalsøgere på udvalgstidspunktet og deres villighed til at indgå i unders $\varnothing$ gelsen, opstod der alligevel en vis skævhed.

I det øjeblik en deltager var færdig med søgningen, blev vedkommende udspurgt om sit kendskab til database søgninger, herunder erfaring med REX, om den aktuelle søgnings forl øb og resultater, om vurdering af REX og evt. erfaring med andre databaser, om evt. hjælp og til sidst om uddannelse og alder.

\section{Køn- og aldersfordeling samt uddannelse}

Af de 55 deltagende personer var 24 kvinder og 31 mænd. Aldersmæssigt lå kvinderne mellem 18 og 58 år, mens mændene befandt sig mellem 19 og 59 år. 
Aldersfordeling på køn ser således ud :

\begin{tabular}{|l|rrrrr|c|}
\hline alder & $<20$ & $20-30$ & $30-40$ & $40-50$ & $50>$ & alle \\
\hline $\mathrm{K}$ & $1(1,8 \%)$ & $16(29,1 \%)$ & $4(7,3 \%)$ & $2(3,6 \%)$ & $1(1,8 \%)$ & $24(43,6 \%)$ \\
$\mathrm{M}$ & $1(1,8 \%)$ & $19(34,5 \%)$ & $6(10,9 \%)$ & $3(5,5 \%)$ & $2(3,7 \%)$ & $31(56,4 \%)$ \\
ialt & $2(3,6 \%)$ & $35(63,6 \%)$ & $10(18,2 \%)$ & $5(9,1 \%)$ & $3(5,5 \%)$ & $55(100 \%)$ \\
\hline
\end{tabular}

Det vil sige, at aldersgrupperne op til 30 år udgjorde ca. 66 pct. af deltagerne og at gruppen over 30 år omfattede ca. 34 pct. Det svarer nogenlunde til tilsvarende undersøgelser i udenlandske forskningsbiblioteker.

Der var 11 færdiguddannede. Heraf var de 10 magistre, mens 1 var bibliotekar (ikke ansat ved Det kongelige Bibliotek). Af de resterende var 38 under videregående uddannelse på Københavns Universitet, 2 var udenlandske studerende under særlige kurser på universitetet, 1 uddannede sig til kunstmaler på Kunstakademiet, 1 var studerende på Lærerhøjskolen, 1 studerede på Landbohøjskolen og endelig var der en HF-studerende. Blandt deltagerne var der 11, der havde polit/økonomi som fag ( 5 kvinder, 6 mænd), 7 var inden for socialvidenskab/jura området (3 kvinder, 4 mænd), og 1 studerede naturvidenskab (kvinde). De $\varnothing$ vrige 35 studerede humaniora (15 kvinder, 20 mænd).

Fordelingen mellem færdiguddannede og studerende efter køn ser således ud:

\begin{tabular}{|l|rrr|c|}
\hline & \multicolumn{2}{|c|}{ K } & M & \multicolumn{2}{c|}{ begge } \\
\hline \begin{tabular}{l|rrrr} 
Færdiguddannede \\
Studerende
\end{tabular} & 4 & $(7,3 \%)$ & $7(12,7 \%)$ & $11(20 \%)$ \\
& 20 & $(36,4 \%)$ & $24(43,6 \%)$ & $44 \quad(80 \%)$ \\
\hline
\end{tabular}

De indfangede forsøgspersoner viste sig alle at have akademiske affiliationer. Der var kun en af personerne (en HF-studerende), der ikke havde mindst en studentereksamen som ballast. Desuden var den overvejende gruppe af personer studerende, hvilket ikke er overraskende, da Det kongelige Bibliotek traditionelt betjener lærere og studerende ved Københavns Universitet med bøger og dokumenter. 
Fordelingen efter fag i forhold til alder og køn falder ud på følgende måde: (tallene i parantes angiver pct.)

\begin{tabular}{|l|rrrrr|rrr|}
\hline & $<20$ & $20-30$ & $30-40$ & $40-50$ & $50>$ & $\mathrm{K}$ & $\mathrm{M}$ & begge \\
\hline $\begin{array}{l}\text { hu- } \\
\text { manistiske } \\
\text { fag }\end{array}$ & 1 & 21 & 6 & 4 & 3 & 15 & 20 & 35 \\
sociale & $1,8)$ & $(38,2)$ & $(10,9)$ & $(7,3)$ & $(5,4)$ & $(27,3)$ & $(36,3)$ & $(63,6)$ \\
fag/jura & 1 & 4 & 2 & 0 & 0 & 3 & 4 & 7 \\
$\begin{array}{l}\text { polit/ } \\
\text { фkonomi }\end{array}$ & $(1,8)$ & $(7,4)$ & $(3,6)$ & $(0)$ & $(0)$ & $(5,4)$ & $(7,4)$ & $(12,8)$ \\
$\begin{array}{l}\text { natur- } \\
\text { videnskab }\end{array}$ & 0 & 10 & 2 & 0 & 0 & 5 & 7 & 12 \\
& $(0)$ & $(18,2)$ & $(3,6)$ & $(0)$ & $(0)$ & $(9,1)$ & $(12,7)$ & $(21,8)$ \\
& 0 & 1 & 0 & 0 & 0 & 1 & 0 & 1 \\
\end{tabular}

Der var stort set ikke noget overraskende i fordelingen af personer mellem de 4 opstillede hovedgrupper af fag. Dog skal det påpeges, at i denne unders $\emptyset$ gelse udgjorde de sociale fag og jura kun 12,8 pct. af den totale masse, hvilket i nogen grad er i modstrid med den gængse opfattelse af, hvor stor en del af lånerskaren, der er beskæftiget med disse fag. Til gengæld fandtes der en forholdsvis stor gruppe af politisk og $\emptyset$ konomisk interesserede $(21,8 \mathrm{pct})$. Det var samtidig den gruppe, der fik meget få og ringe resultater (fund) ud af søgningerne.

De interviewede blev ligeledes bedt om at vurdere deres erfaringer med hensyn til at søge i REX. De kunne vælge mellem fire grader: a) førstegangsbruger, b) ringe erfaring, c) middel erfaring og d) stor erfaring.

Den selvbed ømte erfaring ser således ud (ingen aldersgruppering):

\begin{tabular}{|l|rrrr|rl|}
\hline Erfaring & \multicolumn{1}{|c|}{ K } & \multicolumn{3}{|l|}{ M } & \multicolumn{2}{l|}{ begge } \\
\hline 1. gang & 4 & $(7,3 \%)$ & 0 & $(0 \%)$ & 4 & $(7,3 \%)$ \\
Ringe & 13 & $(23,6 \%)$ & 17 & $(30,9 \%)$ & 30 & $(54,5 \%)$ \\
Middel & 7 & $(12,8 \%)$ & 13 & $(23,6 \%)$ & 20 & $(36,4 \%)$ \\
Stor & 0 & $(0 \%)$ & 1 & $(1,8 \%)$ & 1 & $(1,8 \%)$ \\
\hline
\end{tabular}

Heraf ses, at kvinderne synes positive $i$ at tage online systemet $i$ brug, men er mere usikre eller beskedne i vurderingen af deres fortrolighed med REX onlinekatalog. Blandt kvinderne syntes der ikke aldersmæssigt at være forskel på lysten til at lære REX at kende, da den yngste førstegangsbruger var 20 år og den ældste 58 år. Mændene synes mere sikre på deres egen er- 
faring, men en ret stor gruppe mente dog tilsyneladende, at de ikke var så gode til at søge i REX. Denne mere usikre holdning hos mændene var især udtalt i gruppen over 40 år.

\section{Søgestrategier}

Den altovervejende del af deltagerne (ca. 78 pct) begyndte deres søgninger i fritekst, dvs. uden søgekoder. Af dem, der fortsatte søgninger ved egen hjælp, anvendte ca. 78 pct. stadig fritekst muligheden. Ved trediegangss $\varnothing$ gninger uden hjælp lå fritekstsøgningerne stadig ret højt, på 69 pct. I den fjerde søgning uden hjælp lå fritekstsøgningerne igen på ca. 78 pct. Det betød, at søgninger med koder lå nogenlunde konstant på ca. 25 pct. og at fritekstsøgningerne var på ca. 75 pct. i gennemsnit.

Inden for søgninger i fritekst i førstegangssøgningerne var forfatters $\emptyset$ gningerne mest populære, ca. 37 pct., mens titelsøgningerne i fritekst lå på ca. 29 pct. Søgninger på forfatter var i det hele taget det hyppigste, selv når s $\emptyset$ gekoden $\mathrm{fo}=$ (forfatter) regnes med. Blandt søgekoderne var de mest benyttede $\mathrm{fo}=$, em $=($ emne $)$ og ti=(titel). Det syntes som om at fo $=$ og em $=$ søgekoderne var lige populære. Søgekoden ti= var kun anvendt ganske få gange efter tredie søgning. Klassifikationskoderne $\mathrm{kl}=\mathrm{og} \mathrm{ks}=\mathrm{blev}$ anvendt meget lidt og mest i de sidste søgninger, som en slags sidste fors $\emptyset$ g. 10 pct. af deltagerne begrundede det med, at de øvrige søgninger (f.eks. på titel og/eller forfatter) havde givet meget lidt eller intet brugeligt resultat.

Kombinationsoperatorerne $o g$, eller og ikke var kun kendt af et fåtal af de interviewede. I denne unders $\emptyset$ gelse blev kun $o g$-kombinationen anvendt og i de fire første søgninger var det af 27,5 pct. af deltagerne. Den mest benyttede kombination var ord og ord. Kombinationen forfatter og forfatter var dernæst den populæreste.

Trunkering blev kun anvendt meget sjældent og kun én gang i de fire første søgninger. En enkelt deltager fors $\emptyset$ gte 2 gange at anvende venstretrunkering, hvilket ikke var muligt i REX på daværende tidspunkt, men nu er muligt med titelkoden $\mathrm{ti}=$.

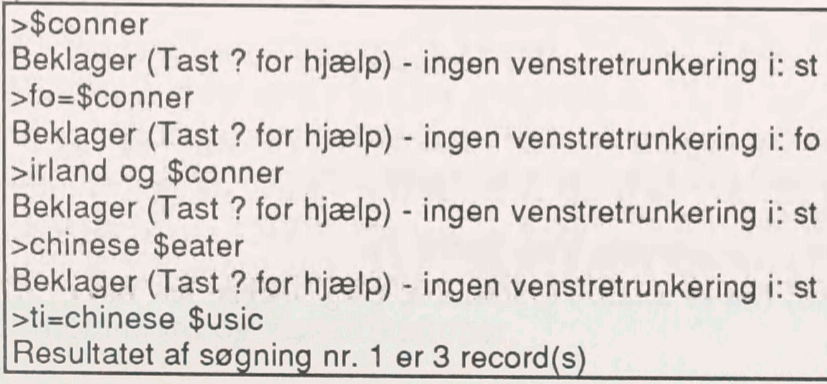


Systemet fortalte søgeren, at venstretrunkering ikke er mulig, men deltageren fors $\emptyset$ gte alligevel efter denne besked én gang til. Dette afslørede en mistillid til enten systemet eller ens egen formåen ved søgninger.

I andre tilfælde, hvor systemet gav negative resultater (svaret var 0 record(s)), troede brugeren ikke på beskeden, men gentog samme søgning identisk med den, der gav 0 fund. Denne operation behøvede ikke nødvendigvis at foregå lige efter første fors $\emptyset \mathrm{g}$, men kunne komme senere i et søgeforløb. Det kunne selvfølgelig være glemsomhed, men det syntes, som om disse identiske søgninger var bevidste ("hvis nu der alligevel var noget"). Se for eksempel følgende søgehistorie:

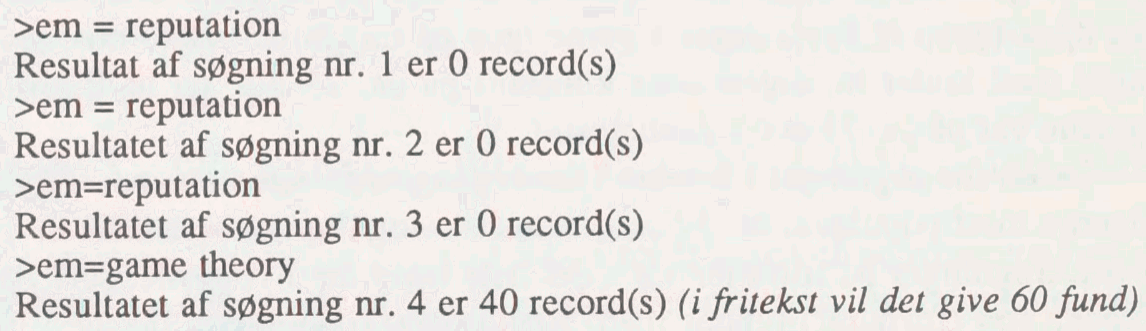

Ingen af deltagerne afbrød deres søgninger p.g.a. 0 fund (record) i de første søgninger. Der var altid et eller andet fund. Deltagerne fortsatte ufortrødent selvom op til de fire første søgninger endte resultatløst.

\section{Fejlslag og stavefejl}

Fejlslag og deciderede stavefejl forekom i op til 20 pct af alle søgninger. Hovedparten af fejlslagene blev rettet før vis-kommandoen blev aktiveret. Det var ikke muligt at verificere hvor mange af de negative resultater ( 0 fund), der skyldtes stavefejl. I ét tilfælde skyldtes det ganske givet en stavefejl af et forfatternavn, som følgende eksempel kan vise:

1: Winnicut (0 fund) (andre opslag foretages)

2: fo=winnicut ( 0 fund) (samme opslag som tidligere nu bare med søgekode)

3: Winicut (0 fund) (opslag minus et $n$ ) (andre opslag foretages)

4: fo=winecut (0 fund) (nu minus et $n$ og andet $i$ erstattet af $e$ )

5: Winicut (0 fund) (samme som 3)

6: winnicut (0 fund) (samme som 1 og delvis 2)

7: winnecut (0 fund) (nu er andet i erstattet af e og bruger gav op) 
Brugeren søgte formodentlig forfatteren D.W. Winnicott, der bl.a. skriver værker indenfor sociologi, som var det emne brugeren eftersøgte. (fo=Winnicott giver 39 fund).

En anden hyppig misforståelse er rækkefølgen af efternavn og fornavn. 10 pct. af deltagerne indtastede først fornavn efterfulgt af efternavn. I nogle tilfælde kan brugeren få fund på denne type af opslag, da der i nogle REXposter er indlagt en gentagelse af forfatternavne, som de er trykt på forsiden af bøgerne, men ikke alle poster har dette. Desuden er der mulighed for forglemmelse af mellemnavne etc. F.eks. søgte en deltager på Margaret Mahler, hvilket gav 0 fund. Hvis vedkommende havde vidst, at denne forfatter er bedst kendt som Margaret S. Mahler, ville der være 15 fund på et sådant opslag, mens det regulære opslag på Mahler, Margaret ville give ialt 18 fund.

Nogle deltagere var klar over en databases ensidighed, hvad angår stavning, og de søgte derfor på forskellige stavemåder også når det kunne tillægges forskellige sprogs stavemåder af velkendte ord (ofte taget fra latin). Et eksempel kan belyse dette :

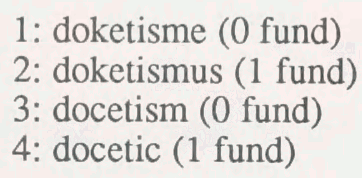

Brugeren kunne have fors $\emptyset \mathrm{gt}$ sig med maskering (ingen i unders $\emptyset$ gelsen anvendte denne mulighed), således at der kunne søges på do\$eti...etc., men i praksis er det ikke anvendeligt, da systemet svarer: "beklager - kommandoen kræver for mange maskin-ressourcer."

For nogle få deltagere skete der en sammenblanding af sprog, når de søgte udenlandsk litteratur om et emne. F.eks. søgte en deltager efter engelsksprogede bøger om America, men slog op på Amerika.

\section{Deltagernes resultater af søgningerne efter eget udsagn}

I interviewene blev deltagerne spurgt om, hvor mange anvendelige fund de fik, som ville resultere i lån fra biblioteket. Ud af de 55 deltagere var der 9 , som ikke fik det resultat, de kom efter. To af de 9 fik dog noget helt andet end det, de søgte. Seks erklærede, at de ikke var tilfredse med det antal titler, de fandt frem i REX. De kunne godt bruge flere titler. Det vides ikke, om denne mangel på titler skyldes ukendskab til REX systemets søgemuligheder eller til emneord og klassifikationer. 
Af de 9, der ikke fik nogle records, var de 4 søgninger inden for sprog og historie. Søgningerne var enkle, og deltagerne var tilsyneladende ude efter bestemte værker (eller forfattere) eller stærkt afgrænsede emner. 2 af søgningerne med negativt resultat var søgninger inden for samfundsvidenskab (kultursociologi og antropologi). Den ene søgning gik både på forfatter og emne inden for engelsksprogede værker, mens den anden søgte på emne med søgekoder inden for både dansk- og engelsksprogede bøger. De sidste 3 var s $\emptyset$ gninger inden for $\emptyset$ konomi både på dansk og engelsk. Den ene på titel og forfatter (i dette tilfælde en korporation), mens de to andre især var på emne.

Når der søgtes efter danske bøger, som brugerne oplyste, de kendte, var det ofte tilfældet, at de ikke fandtes i REX! De søgninger, der blev foretaget inden for $\varnothing$ konomi var i det hele taget dem, der gav færrest resultater og mange uvedkommende fund. Dette gjaldt især de danske bøger. Den nyere danske bogmasse i REX synes derfor ikke at være fuldkommen, hvilket skabte nogle frustrationer hos adskillige deltagere.

\section{Hjælp til søgninger}

Tre af deltagerne måtte have introduktion til REX, da de aldrig tidligere havde $s ø \mathrm{gt}$ i databaser.

Ca. 47 pct. ialt havde behov for hjælp på et eller andet tidspunkt i deres søgninger.

De fleste - ca 75 pct . - bad personalet om hjælp, ca. 15 pct. hentede hjælp i de trykte vejledninger og de resterende 10 pct. anvendte hjælpeskærme, dog først efter at personalet i de fleste tilfælde (90 pct.) havde gjort opmærksom på denne mulighed. Ca. 74 pct. fik hjælp til at aktivere oversigtsformatet $f 1$, som de derefter udtrykte tilfredshed med.

Nogle få deltagere fik hjælp til at benytte hjælpeskærmene om institutterne på Københavns Universitet, hvilket er vigtigt, da en del bøger kun findes på universitetet. I det hele taget skabte fund af bøger tilhørende universitetet problemer, da signaturangivelsens bogstavkode ikke svarer til det opslag, en låner skal indtaste på skærmen for at få den nødvendige oplysning om bogens hjemsted. F.eks. er der angivet som signatur i REX: UnReK 2. Låner taster ?UnReK2, men får svaret: syntaksfejl. Den generelle hjælpeskærm om institutter på Københavns Universitet (?kuinst) anviser, at bogstavkoden skal indtastes med små bogstaver. Hvis låner taster ?unrek 2 fås dog stadig beskeden: syntaksfejl. Den korrekte udgave af indtastningen er ? unrek, som så giver det svar, at det drejer sig om Instituttet for Religionshistorie og Kristendomskundskab, som er delt i 2 afdelinger. 
Andre spørgsmål gik på emnekoder og klassifikationskoder samt på ogkombinationen.

Alt i alt kan det siges, at der stadigvæk synes at være behov for hjælp til søgninger, og at hjælpen især skal ydes af personalet. Omkring 15 pct. af alle deltagerne udtrykte utilfredshed med hjælpeskærmene. En deltager fandt dem endog uforståelige, og udtrykte det således: "For meget EDB sprog".

\section{Deltagernes vurdering af søgbarheden i REX}

Deltagerne i undersøgelsen blev bedt om at vurdere REX, og hvis de kendte andre edb-baser, at vurdere REX i forhold til dem. En fjerdedel af deltagerne kendte andre baser og brugte dem forholdsvis jævnligt. Lidt under halvdelen af alle interviewede mente, at REX var let at anvende (47,3 pct.). Næsten lige så mange (en person mindre) syntes, at REX var nogenlunde let at bruge. Kun 4 (7,3 pct.) udtrykte, at REX var besværlig. En af dem (en mandlig kunstakademistuderende) udtrykte stærk mistillid til edb-søgninger, da han mente, at: "maskinen styrer mig". En kvindelig studerende inden for $\emptyset$ konomi mente, at Handelsh $\varnothing j$ skolens database var langt nemmere at anvende end REX. En mandlig økonomistuderende udtrykte sin glæde ved samme højskoles søgesystem, hvor bl.a. "bladre op og ned" funktionen var nem og brugervenlig i modsætning til REX systemet med indtastning af søgeset og record nummer. En enkelt kvindelig kultursociologistuderende fandt ALBA nemmere.

Der er ikke en klar sammenhæng mellem alder og opfattelsen af systemets tilgængelighed. Måske kan der spores en mere negativ indstilling jo højere alderen er, men ingen af de ældste i undersøgelsen fandt REX besværlig, snarere nogenlunde let. Der synes at være en lille sammenhæng mellem negative resultater af søgninger og vurderingen af REX. De fleste af dem, der fik negative resultater, vurderede REX som nogenlunde let, mens kun én udtrykte, at REX var besværlig. 5 af brugerne med negativt resultat vurderede REX som en let søgebase. I sammenligningen med andre baser mente kun en ud af de seks, der havde negative resultater i deres søgninger, at REX var mere besværlig end andre databaser. De andre 5 betragtede REX lige så let som andre.

\section{Konklusion}

I nærværende undersøgelse var 80 pct. af deltagerne studerende. Ingen af deltagerne havde et godt kendskab til REX og i hovedparten af søgningerne an- 
vendtes kun ganske få af de søgemuligheder REX indeholder. Ca. 25 pct. anvendte søgekoder, og det var stort set kun fordelt på søgekoderne $f o=, e m=$ og $t i=$. Kun én af de boolske operatorer, og-kombinationen, blev anvendt, og i de 4 første søgninger blev denne operator kun anvendt i ca. 25 pct. af søgningerne. Trunkeringsfaciliteten blev uhyre sjældent benyttet, og maskeringsmuligheden blev slet ikke brugt. Mere avancerede kombinationer af søgekoder var ligeledes næsten ukendte af deltagerne, hvor der f.eks. kunne kombineres mellem materiale og titel, som når der søgtes efter tidsskrifter: $m a=p e r i$ og $t i=$. Tidsskrifts $\varnothing$ gningerne er besværlige og ingen af deltagerne kendte en anden mulighed for let $\varsigma \emptyset$ gning: $l t=($ titel). List funktionen var der heller ingen, der benyttede.

Søgningerne gik mest på forfatter og dernæst på titel. Der var en højere negativ frekvens af fund på titel (ca. 40 pct.) end på forfatters $\emptyset$ gninger (ca. 30 pct.). Det er vanskeligt at vurdere om deltagerne fik tilstrækkeligt ud af deres søgninger, men 10 (18 pct.) af dem udtrykte bestemt, at der kom for få titler frem på skærmen. Søgemulighederne i REX er måske gode nok, men det er helt klart, at deltagerne ikke kender systemet tilstrækkeligt til at få en udtømmende litteraturdækning. Især hvis de er overladt til sig selv. Ca. 88 pct. af alle hjælpespørgsmål blev stillet til en bibliotekar, kun ca. 11 pct. af problemerne blev forsøgt løst via hjælpeskærmene. Derfor er der brug for en kvalificeret hjælp fra en referencebibliotekar eller en forskningsbibliotekar.

Deltagernes vurdering af REX er positiv, kun 4 (7,3 pct.) betegnede REX som besværlig. I sammenligning med andre edb-baser var REX stadigvæk anset som relativ let. 4 betragtede dog REX som mere besværlig end andre baser, mens 3 deltagere mente, at REX var lettere end andre. 